\title{
A DETAILED OXYGEN-18 PROFILE FROM THE GREENLAND ICE-SHEET MARGIN THROUGH THE WISCONSINANHOLOCENE TRANSITION
}

\author{
(Abstract) \\ by
}

Niels Reeh, Anne Letréguilly and Hans Oerter

(Alfred-Wegener-Institut für Polar- und Meeresforschung, Postfach 120161, D-2850 Bremerhaven, Federal Republic of Germany)

About 1500 surface-ice samples for $\delta^{18} \mathrm{O}$ analysis were collected in the 1988 field season along a $750 \mathrm{~m}$ profile perpendicular to the margin of the Greenland ice sheet at Pakitsoq, $c a 40 \mathrm{~km}$ north-east of Jakobshavn, central West Greenland. The purpose of the study was to evaluate how well the continuity of the layer sequence is preserved in ice-margin records, a question of crucial importance for evaluating the potential yield of using ice margins as "mining areas" for easily accessible old ice for climate and environmental studies.

More than half of the 1500 samples were taken continuously as $20 \mathrm{~cm}$ samples along a $170 \mathrm{~m}$ section through the Wisconsinan-Holocene transition which, previously, had been located at the surface of the ice margin. Along this transition section $\delta^{18} \mathrm{O}$ values decrease by about $6 \%$ from -31.5 to $37.5 \%$ on an average. Detailed studies were made of surface elevations and surface structures (e.g. blue bands) along the "horizontal core" profile which, moreover, was photographed section by section, thus enabling the 8 -record to be correlated with surface features.

Results of the $\delta^{18} \mathrm{O}$ analyses are promising. Even though ice from the blue bands has $\delta$-values that are $7-8 \%$ higher than those of the surrounding white ice, there seems to be no discontinuity in the white-ice 8 -record across the blue bands.

\section{CAN MILANKOVITCH VARIATIONS INITIATE THE GROWTH OF ICE SHEETS IN A GLOBAL CIRCULATION MODEL?}

\section{(Abstract)}

by

David Rind

(Goddard Institute for Space Studies, 2880 Broadway, New York, NY 10025, U.S.A.)

\begin{abstract}
The GISS climate model is used to investigate whether the growth of ice sheets could have been initiated by solar insolation variations. Three different orbital configurations are used, corresponding to $116000 \mathrm{yr}$ B.P., $106000 \mathrm{yr}$ B.P., and a modified insolation field with greater reductions in summer insolation at high northern latitudes. The time periods chosen are those in which geophysical evidence implies that ice sheets were growing rapidly.

The results show that the model fails to maintain snow cover through the summer at locations of suspected initiation of the major ice sheets, despite the reduced summer insolation. When $10 \mathrm{~m}$-thick ice was inserted in all locations where continental ice sheets existed during the last glacial maximum, the model failed to maintain it as well:
\end{abstract}

the ice would melt away in less than five years. Only cooling the ocean to its full ice-age value allowed the model to keep any of the additional ice, and then only in a very restricted region in northern Baffin Island.

The experiments indicate there is a wide discrepancy between the model's response to Milankovitch variations and the geophysical evidence of ice sheet initiation. As the model failed to grow or sustain low-elevation ice during the time of high latitude maximum solar radiation reduction $(120000-100000 \mathrm{yr}$ B.P.), it is unlikely it could have done so at any time within the last several hundred thousand years. Either the model is not nearly sensitive enough, or we do not understand the connection between Milankovitch variations and the growth of ice sheets. 